\title{
HUKUM PAJAK DAN IMPLEMENTASINYA BAGI KESEJAHTERAAN RAKYAT ${ }^{*}$
}

\author{
Dwi Sulastyawati ${ }^{1}$ \\ Permalink: https://www.academia.edu/9989886
}

\begin{abstract}
Tax Law and its Implementation for Social Welfare. Tax is one of the economic instruments of a country. Some of these taxes as a source of national income lasts more than $50 \%$ of national income. When a country has higher income taxes for example, more jobs can be created, reducing unemployment, better education and health care. Moreover, a good instrument for the distribution of income. However, the distribution of income becomes biggest economic problem today. Where the rich get richer and poor get poorer. Tax becomes an instrument to reduce the mismatch of income whether it affects the welfare of the people or not. This issue will be discussed in this paper.
\end{abstract}

Keywords: Tax, Tax Law, Tax utilization

\begin{abstract}
Abstrak: Hukum Pajak dan Implementasinya Bagi Kesejahteraan Rakyat. Pajak merupakan salah satu instrumen ekonomi suatu negara. Sebagian pajak sebagai sumber pendapatan nasional berlangsung lebih dari 50\% dari pendapatan nasional. Ketika suatu negara memiliki pendapatan yang lebih tinggi dari pajak misalnya, lebih banyak pekerjaan dapat diciptakan, pengangguran mengurangi, baik pendidikan, pelayanan kesehatan dapat mencapai. Dan juga instrumen yang baik untuk distribusi pendapatan. Sedangkan distribusi pendapatan menjadi masalah terbesar saat ini ekonomi. Dimana kaya semakin kaya dan miskin semakin miskin. Ketika pajak menjadi instrumen untuk mengurangi ketidakcocokan pendapatan apakah itu mempengaruhi kesejahteraan rakyat atau tidak makalah ini akan menguraikan bahwa.
\end{abstract}

Kata Kunci: Pajak, Hukum Pajak, Pajak Pemanfaatan

* Diterima tanggal naskah diterima: 05 April 2014, direvisi: 30 Mei 2014, disetujui untuk terbit: 11 Juni 2014.

${ }^{1}$ Sekolah Tinggi Agama Islam Negeri (STAIN) Curup Bengkulu. Alamat: Jl. AK. Gani No. 1 Curup Bengkulu. E-mail: dwisulastyawati@yahoo.co.id 


\section{Pendahuluan}

Negara Republik Indonesia adalah Negara Hukum berdasarkan Pancasila dan Undang-Undang Dasar 1945, dalam perkembangannya telah menghasilkan pembangunan yang pesat dalam kehidupan nasional yang perlu dilanjutkan dengan dukungan Pemerintah dan seluruh potensi masyarakat. Dalam menyelenggarakan pemerintahan, negara mempunyai kewajiban untuk menjaga kepentingan rakyatnya, baik dalam bidang kesejahteraan, keamanan, pertahanan, maupun kecerdasan kehidupannya. ${ }^{2} \mathrm{Hal}$ ini sesuai dengan tujuan negara yang dicantumkan di dalam Pembukaan Undang-Undang Dasar 1945 yang berbunyi "melindungi segenap bangsa Indonesia dan seluruh tumpah darah Indonesia dan untuk memajukan kesejahteraan umum, mencerdaskan kehidupan bangsa dan ikut melaksanakan ketertiban dunia yang berdasarkan keadilan sosial".

Keberhasilan pelaksanaan pembangunan memerlukan dana yang tidak sedikit, kebutuhan untuk pembangunan sifatnya proporsional dan disesuaikan dengan kebutuhan pembangunan yang sedang dan akan berlangsung. Kebutuhan akan dana pembangunan dapat diperoleh melalui berbagai cara yang kesemuanya diharapkan dapat memperkuat sektor keuangan negara dalam hal ini adalah sektor pajak.

Pajak merupakan sumber pendapatan negara yang sangat penting bagi penyelengaraan pemerintahan dan pelaksanaan pembangunan nasional. Sehingga Pemerintah menempatkan kewajiban perpajakan sebagai salah satu pewujudan kewajiban kenegaraan yang merupakan sarana dalam pembiayaan Negara dalam Pembangunan Nasional guna tercapainya tujuan negara. Penting dan strategisnya peran serta sektor perpajakan dalam penyelenggaraan pemerintah dapat dilihat pada Anggaran Belanja Negara (APBN) dan Rancangan APBN setiap tahun yang disampaikan pemerintah, yaitu terjadinya peningkatan persentase sumbangan pajak dari tahun ke tahun.

Sumber Penerimaan Negara berdasarkan Undang-Undang APBN terdiri dari Penerimaan Pajak, Penerimaan Negara Bukan Pajak (PNBP), dan Hibah. Kebijakan Pemerintah di bidang pendapatan negara dan hibah diarahkan untuk mendukung kebijakan fiskal yang berkesinambungan melalui upaya optimalisasi pendapatan negara dan hibah, khususnya penerimaan dalam negeri. Hal ini sesuai dengan peran pendapatan dan hibah sebagai sumber pendanaan program-program pembangunan.

Sebagai kontributor utama bagi penerimaan dalam negeri dalam tahun 2010, kebijakan pendapatan negara dan hibah tetap diarahkan untuk optimalisasi penerimaan dalam negeri. Di bidang perpajakan, selain melakukan kebijakan yang bersifat reguler seperti reformasi di bidang administrasi, peraturan perundang-undangan dan pengawasan serta penggalian potensi, antara lain dilakukan melalui peningkatan efisiensi pemeriksaan dan penagihan

\footnotetext{
${ }^{2}$ http://organisasi.org/tujuan_nasional_yang_termaktub_dalam_pembukaan_uud_45_a linea_ke_4_republik_indonesia_ilmu_pendidikan_pmp_dan_ppkn

${ }^{3}$ Alinea keempat Undang-Undang Dasar 1945.

${ }^{4}$ Tjip Ismail, Kumpulan Artikel Kuliah Hukum Pajak, h. 3.
} 
pajak. Di bidang PNBP, kebijakan yang dilakukan Pemerintah untuk mengamankan target PNBP tahun 2010 adalah optimalisasi penerimaan SDA terutama dari migas, peningkatan kinerja BUMN, serta optimalisasi PNBP kementerian/lembaga $(\mathrm{K} / \mathrm{L})$.

Berdasarkan uraian di atas, tampak bahwa pajak merupakan salah satu sumber penerimaan negara yang sangat penting bagi bagi penyelenggaraan pemerintah dan pelaksanaan pembangunan nasional. Penting dan strategisnya peran sektor perpajakan dalam penyelenggaraan pemerintah dapat dilihat pada Anggaran Pendapatan dan Belanja Negara (APBN) dan Rancangan APBN setiap tahun yang disampaikan pemerintah, yaitu terjadinya peningkatan persentase sumbangan perolehan pajak bagi APBN dari tahun ke tahun.

\section{Pengertian Pajak}

Pengertian pajak menurut Undang-undang Nomor 28 tahun 2007 tentang Ketentuan Umum Dan Tata Cara Perpajakan (UU KUP) adalah kontribusi wajib kepada negara oleh orang pribadi atau badan yang bersifat memaksa berdasarkan Undang-Undang, Pajak merupakan kewajiban bernegara yang diatur jelas dalam UUD 1945. Dalam pasal 23 (A)di tegaskan bahwa "pajak dan pungutan lain yang bersifat memaksa untuk keperluan negara diatur dengan undang-undang". Yang sesuai dengan pasal 27 ayat (1).

Pasal 23 (A) UUD 1945 (Amandemen IV), merupakan dasar hukum pungutan pajak di Indonesia yang berbunyi: "Pajak dan pungutan lain yang bersifat memaksa untuk keperluan negara diatur dengan undang-undang".

Berkaitan dengan pajak, ada banyak pengertian yang diberikan oleh para sarjana mengenai apa sebenarnya pajak itu. Definisi pajak menurut P.J.A. Andriani, yaitu berbunyi sebagai berikut:" "Pajak adalah iuran kepada negara (yang dapat dipaksakan) yang terhutang oleh yang wajib membayarnya menurut peraturan-peraturan dengan tidak mendapat prestasi kembali, yang langsung dapat ditunjuk, dan yang gunanya adalah untuk membiayai pengeluaran-pengeluaran umum berhubungan dengan tugas negara untuk menyelenggarakan pemerintahan."

Sebagai perbandingan berikut ini dipaparkan beberapa definisi pajak dari beberapa Sarjana yaitu: ${ }^{6} 1$ ). Definisi Francis, berbunyi: "Pajak adalah bantuan, baik secara langsung maupun tidak yang dipaksakan oleh kekuasaan publik dari penduduk atau dari barang untuk menutup belanja pemerintah." 2). Definisi Deutsche Reichs Abgaben Ordnung (RAO-1919) berbunyi: "Pajak adalah hutang uang secara insidental atau secara periodik (dengan tidak ada kontraprestasinya), yang dipungut oleh badan yang bersyarat umum (negara), untuk memperoleh pendapatan, dimana terjadi suatu tatbestand (sasaran pemajakan), yang karena undang-undang telah menimbulkan hutang pajak." 3). Definisi Edwin R.A. Seligman berbunyi: "Tax is a compulsory contribution from the person, to the government to defray the expenses incured in the

${ }^{5}$ R, Santoso Brotodiharjo, Pengantar Ilmu Hukum Pajak, (Bandung: Rafika Aditama,

${ }^{6} \mathrm{R}$, Santoso Brotodiharjo, Pengantar Ilmu Hukum Pajak, h.3. 
common interest of all, without reference to special benefit confered". Banyak terdengar keberatan atas kalimat "without reference" karena bagaimanapun juga uang-uang pajak tersebut digunakan untuk produksi barang dan jasa, jadi benefit diberikan kepada masyarakat hanya tidak mudah ditunjukkan apalagi secara perorangan.

Banyak para ahli dalam bidang perpajakan yang memberikan pengertian atau definisi yang berbeda-beda mengenai pajak. Namun demikian, berbagai definisi tersebut mempunyai inti atau tujuan yang sama. Definisi yang dapat penulis ajukan adalah sebagai berikut: Pajak ialah iuran rakyat kepada Kas Negara (peralihan kekayaan dari sektor partikelir ke sektor pemerintah) berdasarkan undang-undang (dapat dipaksakan) dengan tiada mendapat jasa timbal (tegen prestatie) yang langsung dapat ditunjuk dan yang digunakan untuk membiayai pengeluaran umum (publiecke uitgaven).

Dengan demikian pajak hanya dapat dipungut oleh pemerintah (baik pusat maupun daerah), dan pemerintah baru dapat memungut pajak berdasarkan undang-undang yang berlaku.

\section{Pajak Instrumen Ekonomi Negara}

Pajak sebagai instrumen perekonomian merupakan sumber pemasukan utama sebuah Negara. Ia merupakan kewajiban setiap warganegara yang diatur dalam UUD 1945. Tetapi pada faktanya pemerintah seringkali mengalami kekurangan atau defisit, sehingga untuk menutupi kekurangan tersebut pemerintah berhutang baik domestik atau luar negeri. Misalnya dengan menerbitkan surat berharga untuk memenuhi kebutuhan pembiayaan jangka pendek.

Pajak merupakan kontribusi utama pemasukan pemerintah, dan pajak juga merupakan sumber belanja negara. Ada dua fungsi pajak yaitu fungsi budgeter dan fungsi budgeter.

Pertama; berfungsi sebagai budgeter ${ }^{7}$, yaitu pajak sebagai sumber dana pemerintah untuk membiayai pengeluaran-pengeluarannya. Fungsi pajak budgeter adalah fungsi yang letaknya disektor publik, dan pajak tersebut merupakan suatu alat untuk memasukkan uang sebanyak-banyaknya kedalam kas negara yang pada waktunya akan digunakan untuk membiayai pengeluaranpengeluaran negara, terutama untuk membiayai pengeluaran rutin, dan apabila setelah itu masih ada sisa (surplus), maka surplus ini dapat digunakan untuk membiayai investasi pemerintah (public saving untuk public invesment).

Kedua; berfungsi sebagai Regulerend ${ }^{8}$ atau mengatur yaitu pajak sebagai alat untuk mengatur atau melaksanakan kebijakan pemerintah dalam bidang sosial dan ekonomi. Pajak mempunyai fungsi mengatur (Regulerend), dalam arti bahwa pajak itu dapat digunakan sebagai alat untuk mengatur atau melaksanakan kebijaksanaan Negara dalam lapangan ekonomi dan sosial dengan fungsi mengaturnya pajak digunakan sebagai suatu alat untuk mencapai tujuan-tujuan tertentu yang letaknya diluar bidang Keuangan dan

\footnotetext{
${ }^{7}$ Munawir S, Pokok-pokok Perpajakan, liberty, Yogyakarta, 1985, h. 4.

${ }^{8}$ Munawir S, Pokok-Pokok Perpajakan, h. 4.
} 
fungsi mengatur itu banyak ditujukan terhadap sektor swasta. Misalnya dalam pajak perseroan salah satu pasal dari ordonansi pajak perseroan 1925 memberi kebebasan dari pajak perseroan atas pengenaan tarif yang rendah terhadap badan-badan koperasi yang berkedudukan di Indonesia.

Dari fungsi yang kedua, apakah pemerintah telah menjalankan fungsi pajak dengan baik, dengan indikasi kesejahteraan bagi rakyat baik di bidang sosial dan ekonomi, dengan tersedianya pelayanan-pelayanan publik yang baik, ketersediaan lapangan kerja, rendahnya tingkat pengangguran, tingginya daya beli masyarakat, dan berkurangnya pendidikan. Apakah hal ini telah tercapai, mengingat dari total seluruh masyarakat, dana pajak yang terkumpul hanya kurang dari $20 \%$.

Ada empat macam tarif pajak: ${ }^{9}$ (1). Tarif sebanding/proporsional, berupa presentase yang tetap, terhadap berapa pun jumlah yang dikenai pajak, sehingga besarnya pajak yang terutang proporsional terhadap besarnya nilai yang dikenai pajak. (2). Tarif tetap, berupa jumlah yang tetap terhadap berapapun jumlah yang dikenai pajak, sehingga besarnya pajak yang terutang adalah tetap. (3). Tarif progresif, presentase tarif yang digunakan semakin besar bila jumlah yang dikenai pajak semakin besar. (4). Tarif degresif, presentase tarif yang digunakan semakin kecil bila jumlah yang digunakan semakin kecil.

Sejalan dengan tema pembangunan nasional dalam RKP 2012, yaitu "Percepatan dan Perluasan Pertumbuhan Ekonomi yang Berkualitas, Inklusif dan Berkeadilan Bagi Peningkatan Kesejahteraan Rakyat", kebijakan alokasi anggaran belanja Negara dalam RAPBN tahun 2012 diarahkan kepada upaya untuk: (1). Mendorong pertumbuhan di daerah melalui pengembangan koridor ekonomi, (2). Membangun infrastruktur yang mendukung terwujudnya keterhubungan wilayah, (3). Mendorong pelaksanaan program perlindungan sosial yang berpihak kepada masyarakat lemah dan tertinggal melalui empat klaster, (4). Penanggulangan kemiskinan dan, (5). Peningkatan kesempatan kerja.

Di samping itu, kebijakan alokasi anggaran juga tetap diarahkan untuk mengoptimalkan sumber-sumber pendapatan negara, meningkatkan efisiensi dan efektivitas belanja negara, serta mengoptimalkan pengelolaan pembiayaan secara hati-hati (prudent) dan meningkatkan pemanfaatannya untuk kegiatan produktif. ${ }^{10}$

Alokasi belanja Pemerintah Pusat 2012 difokuskan untuk memberikan dukungan terhadap: ${ }^{11}(1)$. peningkatan belanja infrastruktur; (2). pelaksanaan klaster 4, yang terdiri dari 6 program utama, dan 3 prioritas utama; (3). program perlindungan sosial dalam bentuk program Jamkesmas, program keluarga harapan $(\mathrm{PKH})$, program nasional pemberdayaan masyarakat (PNPM), BOS, dan raskin; (4). peningkatan belanja untuk bidang

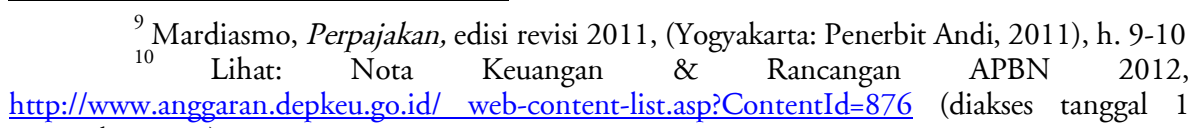
November 2012)

${ }^{11}$ Ibid. 
perekonomian yang ditujukan untuk perluasan dan percepatan pertumbuhan ekonomi yang inklusif dan berkualitas; (5). implementasi anggaran berbasis kinerja oleh $\mathrm{K} / \mathrm{L}$ dengan pendekatan pencapaian output dan outcome; (6). peningkatan kemampuan pertahanan menuju minimum essential force; (7). perbaikan kesejahteraan aparatur Negara dan perluasan kebijakan reformasi birokrasi; (8). pengendalian pengangkatan PNS pusat dan daerah dengan mengarahkan kepada kebijakan zero growth; (9). pengalokasian anggaran subsidi agar lebih tepat sasaran; (10). peningkatan efisiensi dan efektivitas belanja negara; serta (11). pengalokasian anggaran pendidikan 20 persen dari APBN dan mengarahkan pemanfaatan anggarannya untuk meningkatkan aksesibilitas serta kualitas sarana dan prasarana pendidikan.

Berdasarkan arah dan strategi kebijakan fiskal tersebut di atas, maka postur RAPBN 2012 akan meliputi pokok-pokok besaran sebagai berikut: (1). Pendapatan negara dan penerimaan hibah direncanakan mencapai Rp1.292,9 triliun (15,9 persen terhadap PDB), yang berarti mengalami kenaikan sebesar Rp123,0 triliun (10,5 persen) dari target APBN-P tahun 2011. Kenaikan rencana pendapatan negara dan hibah tersebut diharapkan akan didukung oleh kenaikan penerimaan perpajakan. (2). Total belanja negara direncanakan sebesar Rp. 1.418,5 triliun (17,5 persen terhadap PDB). Jumlah ini, berarti menunjukkan peningkatan sebesar Rp97,7 triliun atau 7,4 persen dari pagu anggaran belanja negara dalam APBN-P 2011 sebesar Rp1.320,8 triliun. Belanja pemerintah pusat dalam tahun 2012 direncanakan sebesar Rp954,1 triliun, yang berarti mengalami peningkatan Rp. 45,9 triliun atau 5,1 persen dari paguAPBN-P 2011. Sementara itu, anggaran transfer ke daerah dalam RAPBN tahun 2012 direncanakan sebesar Rp. 464,4 triliun, yang berarti naik Rp. 51,9 triliun atau 12,6 persen dari pagu APBN-P 2011 sebesar Rp. 412,5 triliun. (3). Defisit anggaran diperkirakan sebesar Rp. 125,6 triliun (1,5 persen terhadap PDB). (4). Pembiayaan defisit RAPBN 2012 direncanakan berasal dari sumber-sumber pembiayaan dalam negeri sebesar Rp. 125,9 triliun, dan pembiayaan luar negeri yang diperkirakan sebesar negatif Rp. 0,3 triliun.

Jadi pajak adalah tulang punggung dari pertumbuhan penyelenggaran negara. Diperkirakan pula sekitar 25 juta masyarakat mampu yang belum membayar pajak yang baru tergali potensi dari sumber wajib pajak hanya sebesar $10.4 \%$ dari perkiraan 5 juta badan usaha potensial. ${ }^{12}$

Angka $10.4 \%$ tentunya adalah angka yang relatif kecil karena untuk membiayai defisit ini rencana pembiayaan dianggarkan dari hutang dalam dan luar negeri, jika kita membahas masalah hutang. Menurut Editoral Media Indonesia Edisi 25 November 2011 dengan edisi "Hutang kian menggunung" ${ }^{13}$, Jumlah hutang Negara tahun 2011 sejumlah 1.768 triliun rupiah, sedangkan pada tahun 2001 sejumlah 1.273 triliun rupiah, yang artinya kenaikan hutang negara pertahun naik rata-rata 50 triliun rupiah. Kenaikan

${ }^{12}$ Lihat: Mahendra, PajakSebagaiPilar Negara, Suplemen Tempo edisi 25 Oktober-4 November 2012, KementerianKeuangan RI Direktorat Jenderal Pajak.

13 Lihat: http://www.mediaindonesia.com/editorial/index.php/editorial/detail/908 Diakses 27 November 2011. 
hutang dari 2010-2011 adalah sebesar 19,19 triliun rupiah. Dan jika dibagi dengan 230 juta jiwa, setiap individu rakyat Indonesia menanggung beban hutang sebesar 7,4 juta rupiah. Angka yang cukup fantastis, karena bagaimana hutang Negara bisa habis, jika dari tahun ketahun jumlahnya bertambah.

Dari kondisi ini instrumen pajak sangat dihandalkan untuk pembiayaan belanja Negara, agar Negara bisa mengatasi masalah deficit anggaran, meningkatkan pembelanjaan negara dan upaya menyejahterakan rakyat, agar masyarakat dapat merasakan manfaat penerimaan pajak untuk pembangunan fasilitas pelayanan publik dan infrastruktur, pendidikan murah, kesehatan murah, pertahanan dan keamanan, subsidi BBM, energi dan pangan tertib dan lancar. Selain itu, peran pajak juga sebagai retribusi bagi orang kaya, sehingga setiap masyarakat yang miskin dan kurang mampu akan dialirkan dari dana tersebut karena ketimpangan distribusi pendapatan adalah masalah ekonomi dunia saat ini. Acapkali, orang-orang kaya tersebut melupakan kewajiban Negara dalam bentuk membayar pajak, padahal mereka juga menikmati hasil pajak.

Selain potensi pajak yang bernilai 1,3 ribu triliun, sebenarnya potensi instrumen perekonomian seperti zakat misalnya mencapai nilai 217 triliun (BazNas 2011), sekitar 1/6 nilai riil pajak. Jika kesadaran membayar pajak dan zakat disinergikan sudah barang tentu banyak hal bisa dilakukan demi peningkatan kesejahteraan rakyat.

Saat ini diperkirakan lebih dari 5 juta badan usaha, dan ini belum termasuk usaha mikro. Tapi, dari 5 juta badan usaha itu, cuma sekitar 1,9 juta badan usaha yang terdaftar sebagai wajib pajak badan. Dan yang melaporkan SPT hanya $10,4 \%$ dari potensinya. ${ }^{14}$

Hal ini disebabkan oleh beberapa hambatan pemungutan pajak, menurut Mardiasmo dalam bukunya "Perpajakan Edisi Revisi 2011", hambatan tersebut adalah: ${ }^{15}$

Pertama, Perlawanan Pasif. Masyarakat enggan (pasif) membayar pajak, disebabkan antara lain: (1). Perkembangan intelektual dan moral masyarakat. Masyarakat sudah cerdas menilai kinerja aparatur negara dalam hal perpajakan, perpajakan memang menjadi tulang punggung pendapatan negara, tetapi jika menyimak berita korupsi pajak yang dilakukan beberapa oknum pegawai pajak atau para pejabat birokrasi, membuat masyarakat enggan membayar pajak. (2). Sistem perpajakan yang (mungkin) sulit dipahami. Setiap warga Negara berkewajiban membayar pajak, akan tetapi kebanyakan masyarakat tidak mengerti mekanisme penghitungan pajak, dan hal ini menjadi faktor keengganan masyarakat membayar pajak. (3). Sistem kontrol tidak dapat dilakukan dan dilaksanakan dengan baik. Senada dengan contoh yang telah disebutkan di atas, acapkali kita mendengar para pemegang jabatan yang mengorupsi pajak bumi dan bangunan misalnya, hal ini dikarenakan kurangnya

${ }^{14}$ Pajak Sumber Utama APBN yang belum Tergali Maksimal, [Lihat: Mahendra, Pajak Sebagai Pilar Negara, Suplemen Tempo edisi 25 Oktober-4 November 2012, Kementrian Keuangan RI Direktorat Jenderal Pajak].

${ }^{15}$ Mardiasmo, Perpajakan, h. 8-9. 
sistem kontrol distribusi, pelaporan dan penggunaan pajak, sehingga masyarakat enggan dan ragu membayar pajak, hal ini terbukti dari data yang menunjukkan dari wajib pajak pribadi hanya $14,7 \%$ potensi pajak yang tergali, dan dari wajib pajak badan hanya $10,4 \%$.

Kedua, Perlawanan aktif. Perlawanan aktif meliputi semua usaha dan perbuatan yang secara langsung ditujukan kepada fiskus dengan tujuan untuk menghidari pajak. Bentuknya antara lain: (1). Tax avoidance, usaha meringankan beban pajak dengan tidak melanggar undang-undang. (2). Tax evasion, usaha meringankan pajak dengan cara melanggar undang-undang (menggelapkan pajak).

Salah satu langkah yang bisa diambil untuk meningkatkan penerimaan pajak adalah dengan menerapkan tax amnesty atau pengampunan pajak. ${ }^{16}$ Langkah ini sangat efektif untuk menjaring pajak baru, pasalnya banyak badan usaha yang takut pembayaran pajak harus membayar pajak yang tahun sebelumnya. Sehingga diterapkan tax amnesty yang diperlukan kesadaran masyarakat dan para penegak hukum legowo demi kemakmuran rakyat dimasa yang akan datang.

\section{Pengaruh Pajak Terhadap Kesejahteraan Rakyat}

Peran pajak belum menjawab atau memenuhi kebutuhan rakyat, misalnya infrastruktur jalan, banyak sekali ditemui jalan rusak dan belum diperbaiki, fasilitas jembatan yang masih kurang, akibatnya distribusi barang menjadi terhambat dan menyebabkan ekonomi biaya tinggi.

Dari segi pendidikan pun dirasa kurang, dana pendidikan telah dialokasikan sebesar 20\% dari APBN, dan terjadi kenaikan setiap tahun. Tetapi dampaknya dirasa belum begitu mengena, karena bantuan operasional sekolah (BOS), memberikan nominal yang sangat kecil kepada masyarakat kurang mampu, begitu pun tunjangan yang diberikan kepada guru bantu atau guru tidak tetap, minim sekali. Dana bantuan operasional lebih ditujukan kepada rehabilitasi sarana secara fisik, tetapi harus diakui tunjangan profesi guru cukup menambah tingkat kesejahteraan para guru. Pajak yang besar pastinya akan menambah kualitas pendidikan di Indonesia.

Dari segi pelayanan kesehatan, pelayanan kesehatan dengan program jaminan kesehatan masyarakat (jamkesmas) dengan total dana 7,3 triliun, memang sangat membantu rakyat miskin, yang selama ini merasa anti pasti untuk berobat ke rumah sakit. Namun pelayanan tersebut masih kurang, lembaga kesehatan swasta biasanya bisa memberikan pelayanan dengan baik. Ini berarti, masih dibutuhkan dana lebih besar untuk memberikan kenyamanan kesehatan bagi masyarakat dalam rangka meningkatkan kesehatan masyarakat.

Dari segi pertahanan dan keamanan, peralatan militer Indonesia sudah ketinggalan zaman, tidak heran sering kita simak dalam berita kecelakaan darat,

${ }^{16}$ Lihat: Pajak Sumber Utama APBN yang belum Tergali Maksimal, [Lihat: Mahendra, Pajak Sebagai Pilar Negara, Suplemen Tempo edisi 25 Oktober-4 November 2012, Kementrian Keuangan RI Direktorat Jenderal Pajak]. 
laut dan udara. Hal tersebut dikarenakan karena alat yang digunakan sudah tidak layak pakai.

\section{Upaya Reformasi Perpajakan di Indonesia}

Reformasi Perpajakan dilakukan pemerintah diantaranya dengan cara menindak aparat pajak yang menyalahgunakan wewenangnya. Seperti adanya pemberian teguran, tindakan, sampai pemecatan pegawai Kementrian Keuangan terutama pada Direktorat Jenderal Pajak.

Untuk itu, di samping perbaikan akhlak, moral, dan tanggung jawab pejabat, secara terus-menerus dilakukan perbaikan sistem, administrasi, dan kebijakan perpajakan yang bisa mengurangi pertemuan antara wajib pajak dan petugas.

Paling tidak ada dua lompatan yang siginifikan dalam reformasi pajak di Indonesia, ${ }^{17}$ yaitu; Pertama, pembukaan Kantor wajib pajak besar, diikuti uji coba untuk wajib pajak menengah dan kecil dengan sistem perpajakan modern. Pada Kantor wajib pajak besar tersebut, dibentuk account representative yang bertujuan mengetahui segala tingkah laku, ruang lingkup bisnis, dan segala sesuatu yang berkaitan dangan hak dan kewajiban wajib pajak yang diawasinya (knowing your taxpayer). Dan pelayanan kepada wajib pajak dapat dilakukan secara tuntas pada satu meja.

Kedua, adalah usulan terhadap perubahan atau amendemen undangundang perpajakan, yakni Undang-Undang Ketentuan Umum Perpajakan, Undang-Undang Pajak Penghasilan (PPh), dan Undang-Undang Pajak Pertambahan Nilai (PPN). Intinya adalah mengubah tarif, subyek, dan obyek pajak agar kompetitif.

Pemerintah mengusulkan penurunan tarif PPh badan, menaikkan pendapatan tidak kena pajak dua kali lipat, penyederhanaan tarif $\mathrm{PPh}$ dan PPnBM (pajak penjualan atas barang mewah). Dalam soal subyek dari obyek pajak, pemerintah mengusulkan perluasan agar ada rasa keadilan kepada seluruh wajib pajak.

Dalam soal administrasi, dilakukan berbagai macam penyederhanaan perpajakan, misalnya dalam goal mempercepat proses restitusi, memperpendek waktu penyimpanan dokumen, waktu dan metode pembayaran, dan lain sebagainya. Sebagai imbangannya, dalam amendemen undang-undang tersebut diusulkan penalti tarif lebih tinggi bagi wajib pajak yang sengaja tidak memiliki nomor pokok wajib pajak (NPWP). Selain itu, mereka yang sengaja melakukan penghindaran pajak serta mengisi SPT dangan tidak jujur akan dikenai tindakan hukum yang setimpal.

\section{Penutup}

Pajak merupakan iuran wajib setiap warga negara terhadap bangsa, merupakan elemen utama instrumen perekonomian, tetapi pengaruh pajak terhadap kemakmuran masyarakat dari segi sosial, pendidikan dan ekonomi,

${ }^{17}$ Lihat: Anggito Abimanyu, "Melihat Arah Reformasi Perpajakan", (Makalah: Badan Analisa Fiskal, Departemen Keuangan RI. 
dan pertahanan negara dirasa belum maksimal atau belum begitu mempengaruhi kemakmuran rakyat, dana pajak belum mencukupi untuk memenuhi seluruh kebutuhan rakyat Indonesia, rakyat miskin, pengangguran, rumah sakit murah, pendidikan murah semua sangat kurang. Karena itu pajak sangat berperan dengan pro rakyat dalam memajukan negara. Hal ini dikarenakan, potensi pajak yang tergali dan penggunaan pajak yang belum maksimal. Dengan memahami arti penting pajak, maka diharapkan semakin tinggi kesadaran masyarakat membayar pajak, agar tingkat kesejateraan yang lebih baik dapat dicapai.

Agar pungutan pajak tidak menciderai rasa keadilan masyarakat, maka perlu suatu upaya pemaksaan yang bersifat legal. Legalitas dalam hal ini adalah dengan menyandarkan pungutan pajak melalui undang-undang. Tanpa undang-undang, pemungutan pajak tidak mengikat masyarakat dan tidak sah. Oleh karena pemungutan pajak untuk kepentingan rakyat, maka pemungutan pajak haruslah terlebih dahulu disetujui oleh rakyatnya sebagaimana dinyatakan dalam Pasal 23 ayat (2) UUD 1945 yang telah diamandemenkan dalam Pasal 23A amandemen ke-III Undang-Undang Dasar 1945, yang berbunyi "Pajak dan pungutan lain yang bersifat memaksa untuk keperluan negara diatur dengan undang-undang".

\section{Pustaka Acuan}

Ismail, Tjip, DR., Kumpulan Artikel Kuliah Hukum Pajak

Mahendra, Pajak Sebagai Pilar Negara, Suplemen Tempo edisi 25 Oktober-4

November 2012, Kementerian Keuangan RI Direktorat Jenderal Pajak.

Mardiasmo, Perpajakan, edisi revisi 2011, (Yogyakarta: Penerbit Andi, 2011)

Munawir S, Pokok-pokok Perpajakan, liberty, Yogyakarta, 1985.

Pajak Sumber Utama APBN yang belum Tergali Maksimal, [Lihat: Mahendra, Pajak Sebagai Pilar Negara, Suplemen Tempo edisi 25 Oktober - 4

November 2012, Kementrian Keuangan RI Direktorat Jenderal Pajak].

R, Santoso Brotodiharjo, Pengantar Ilmu Hukum Pajak, (Bandung: Rafika

Aditama, 2003)

Suplemen Tempo edisi 25 Oktober-4 November 2012, Kementrian Keuangan

RI Direktorat Jenderal Pajak

Undang-Undang Dasar Negara Republik Indonesia 1945.

Nota Keuangan\&Rancangan APBN 2012, http://www.anggaran.depkeu.go.id/web-content-

list.asp?ContentId=876 (diaksestanggal 1 November 2012)

http://organisasi.org/tujuan_nasional_yang_termaktub_dalam_pembukaan_uu d_45_alinea_ke_4_republik_indonesia_ilmu_pendidikan_pmp_dan_p pkn

http://www.mediaindonesia.com/editorial/index.php/editorial/detail/908

Diakses 27 November 2011. 